\title{
THE ECOLOGICAL IMPORTANCE OF THE MARGHERITA DI SAVOIA SALTWORKS
}

\section{ZENO*}

Received: 20/08/08

Accepted: 15/12/08
Environmental and Territorial Department

Via C. Colombo 112, 00147 Roma - Italy

*to whom all correspondence should be addressed: e-mail: ciro.zeno@atisale.com

\begin{abstract}
The Margherita di Savoia Saltworks, located in Apulia (South Italy), are the largest productive saltworks in Italy. They are connected with the Apulian wetlands, an important network thanks of its central geographic position, between the east and west of the Mediterranean basin. Several species and habitats of European and international interest (Natura 2000 network, Ramsar list) are present in them.

It plays a significant role as an area of stopover, wintering and breeding along the migratory routes of birds that cross the Mediterranean. The most interesting migratory and wintering species is the Numenius tenuirostris (slender-billed curlew), which is the bird most at risk of extinction in Europe.

Moreover in the early 1990s The Phoenicopterus ruber (greater flamingo) has colonised the reserve in great number, around 6,000 today, making it the largest concentration of the species in mainland Italy.

The Margherita di Savoia saltworks are entirely a man-made area, the characteristics of which (water levels, salinity) are preserved entirely due to sea salt production, which guarantees all the chemical and physical factors necessary for the survival of these habitats. It is also worth noting the type of production adopted in the saltworks, which makes it possible to recover the processing brine, thus eliminating one of the critical factors in the symbiotic relationship between salt production and environmental protection.
\end{abstract}

KEYWORDS: Lake Salpi, long-term salt production, "big beam" harvest, Apulian wetlands, Natura 2000 network, greater flamingo.

\section{THE MARGHERITA DI SAVOIA SALTWOKS}

The Margherita di Savoia saltworks are the largest marine saltworks in Italy, with average annual production of approximately 5,500,000 quintals of salt, placing them amongst the top European saltworks in terms of volume and size.

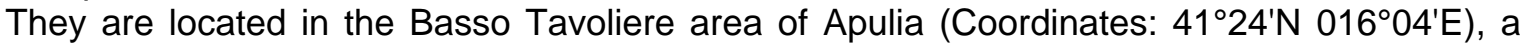
region in Southern Italy, immediately behind the Gargano promontory. They take their name from the town of Margherita di Savoia.

The saltworks run lengthways, parallel to the Adriatic coast, for a distance of approximately $20 \mathrm{~km}$, with a maximum width of $4 \mathrm{~km}$. They cover a surface area of approximately 4000 hectares, with 3,781 subject to protection.

The Margherita di Savoia saltworks do not have a precise date of birth. There was originally a vast coastal lagoon on the site of today's saltworks. This lagoon was known as lake Salpi and was formed of brackish water and salt marshes. It gave its name to the ancient Salapia, the Daunian lagoon city. ${ }^{1}$ Following periodic episodes of sea water flooding the land behind the dunes, the evaporation formed extensive salt incrustations. ${ }^{2}$ This was probably the event that

\footnotetext{
${ }^{1}$ The ancient Daunians inhabited the northern part of Apulia, including the Gargano district from the $8^{\text {th }}$ century B.C. onwards

${ }^{2}$ Undoubtedly, this area possesses all the factors that encourage the production of sea salt. First and foremost, the nature of the terrain: the salt works lie in a naturally impermeable basin comprised of silt banks with flaser bedding with an
} 
caused man to become interested in this site, setting it aside for salt production. This activity has continued uninterrupted over the centuries, right up to today.

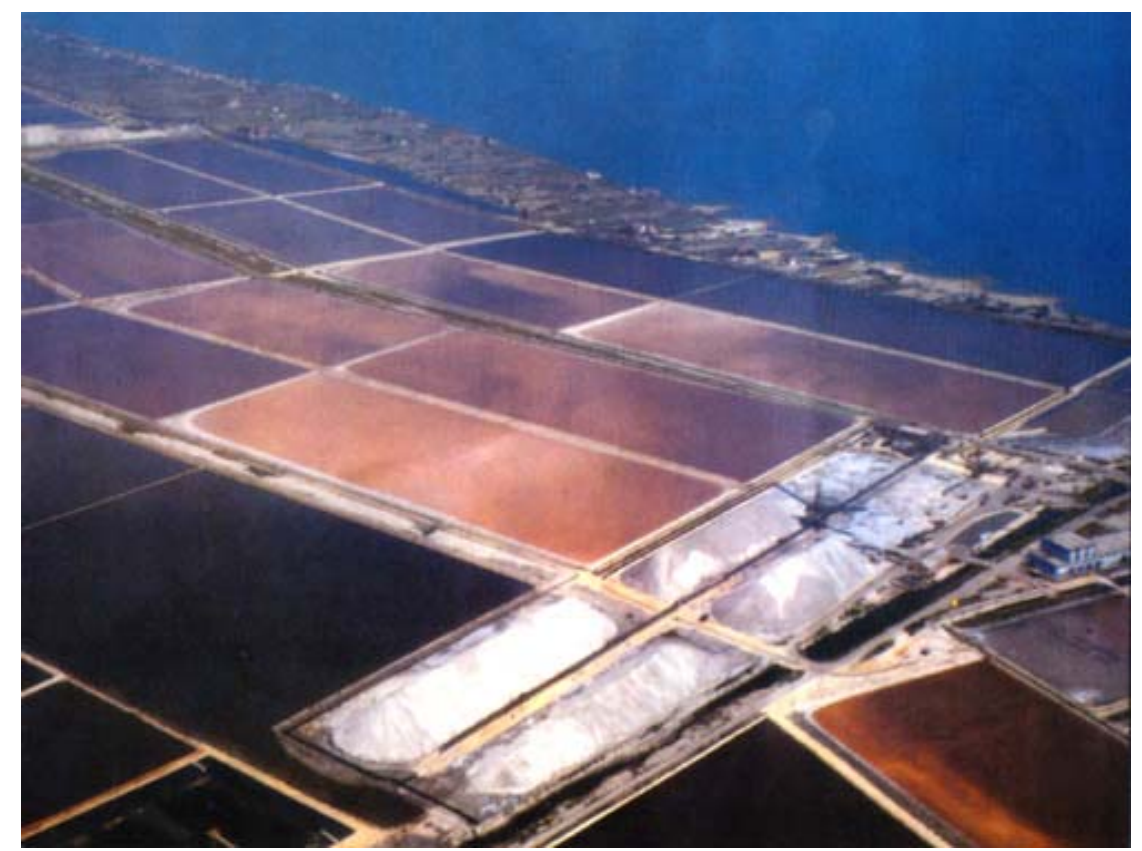

Figure 1. Margherita di Savoia saltworks

The Margherita di Savoia saltworks have always been eminently productive and have thus been a much sought after prize for the various peoples who have had control of them from the 6th century B.C., over the course of at least 2,500 years. As a result, the settlements that developed in the area have been destroyed and rebuilt many times over the centuries. The vicinity of lake Salpi also made the zone subject to malaria. Following major reclamation work in 1936 (Salpi Nuovo) and the 1950s (Alma Dannata), the entire lake was annexed to the salt works, considerably increasing their surface area. It was during this period that the theoretical study of Italian salt works reached its highest level of expression, developing a precise physical and mathematical model for the salt production process (Iommi, 1941), which was used to remodel Italian saltworks and remained substantially unchanged until the mid-1980s. On the basis of this theory, the salt evaporation pond, which is seven times larger than the salt pan, should be subdivided into four zones of increasing saline density, until reaching the maximum density of $25.7^{\circ} \mathrm{Be}$. At this point, the sodium chloride begins to precipitate and the water is poured into the salt pans.

Since the mid-1980s, following the economic crisis in the sector, a new method of deposited salt production has been implemented. This is known as long-term production and is designed to make a significant reduction in production and operating costs.

During this process, the salt produced during the salt-extraction campaign (May - September) is not collected, but left deposited on the bottom of the salt pans. This process is repeated for 4-5 years. At the end of the cycle, there are several superimposed layers, with a total thickness that varies from 50 to $60 \mathrm{~cm}$. In order to protect the layer of salt deposited on the bottom of the salt pans from atmospheric agents, the processing waters (those formed when the salt pans are emptied for harvesting) are used to form a protective cover of $30-40 \mathrm{~cm}$ thick.

average impermeability coefficient of approximately $10^{-6} \mathrm{~cm} / \mathrm{s}$, which persists on clastic quaternary terrain of different compositions and granulometry.

The meteorological data is also undoubtedly favourable, with the average annual temperature being $16^{\circ} \mathrm{C}$. In the period from May-October, the average maximum monthly temperature climbs to almost $23^{\circ} \mathrm{C}$ in May and $30-31^{\circ} \mathrm{C}$ in July and August, then falling to around $22^{\circ} \mathrm{C}$ in October. Thanks to the favourable thermal conditions and good ventilation, evaporation reaches very high values over the course of the year $(1,665.4 \mathrm{~mm})$, almost $70 \%$ of which occurs in the six months from May to October. Lastly, the pluviometric conditions are also extremely good and it should be pointed out that Apulia is home to the two areas with the lowest rainfall in all of mainland Italy. 


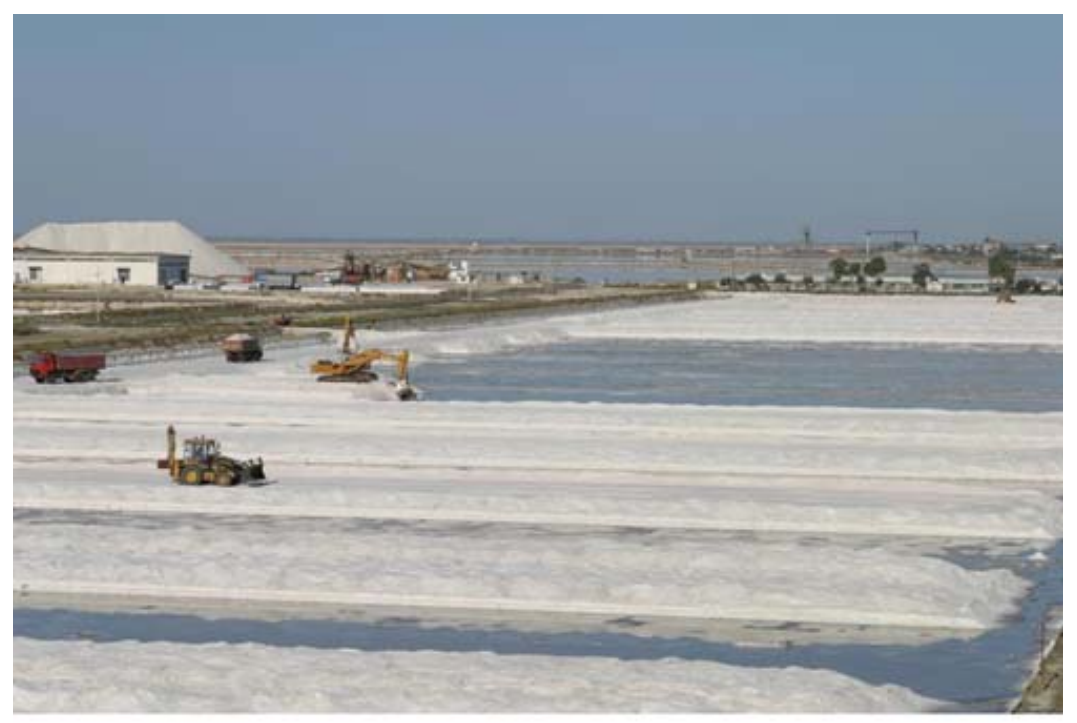

Figure 2. Salt Harvest

The salt pans are harvested on a six-monthly basis using the "big beam" harvest method, which has led to noticeable simplification of the harvesting system. In fact, the thickness of the crust of salt deposited in the salt pans allows a certain number of diggers (3 or 4) to descend directly into the salt pan and form roads of salt (the so-called "big beams"). The thickness of these roads is double that of the crust. A scraper then compacts the "beams", enabling the lorries to descend directly into the salt pan for loading by the diggers.

Several advantages have been made apparent by the adoption of long-term production and "beam" harvesting:

1. The harvest is separated from the production phase - something that is essential in the case of annual production. The harvest can therefore be scheduled on the basis of market requirements or quieter times of year at the plant, such as March and October.

2. The bottoms of the salt pans no longer require maintenance work, which involved compacting and pressing them so as to have completely flat bottoms.

3. The processing brine (bittern), which is normally disposed of at sea by salt works that implement annual harvests and is one of the critical factors in the relationship between sea salt production and the environment (Davis, 1999), are instead reused to form a protective cover for the salt pans.

4. Less anthropogenic impact on the salt pans, inasmuch as the same area is harvested every five years.

5. Low anthropogenic impact as regards the harvesting method, due to the simplicity of the means and the small number of people involved: 4 diggers, one scraper, 10 lorries and 10 operators.

\section{THE APULIAN WETLANDS}

Apulia is home to numerous and extremely diverse coastal wetlands, which, environmentally speaking, are some of the most important in Italy. This system is formed of 38 wetland zones, covering a total area of approximately $24,000-26,000$ hectares. In addition to providing extensive and varied habitats, it is also important because of its central geographic position, acting as a bridge between the east and west of the Mediterranean basin. It plays a significant role as an area of stopover, wintering and breeding along the migratory routes of birds that cross the Mediterranean. In particular, the large salt work complex is an irreplaceable stopping and nesting point for the thousands of migratory birds that visit the area in the winter months on their return from the Balkans, after crossing the Adriatic. 
23 Torre mozza; 24 Bacini di Ugento; 25 I. San AndreaPunta Pizzo; 26 Palude del Capitano; 27 P. Cesareo; 28 Palude del Conte; 29 Torre Colimena-Salina dei Monaci; 30 Fiume Chitro; 31 Torrente Borraco; 32 Saline di Taranto; 33 Sorgente Tara; 34 Fiume Lenne; 35 Fiume lato; 36 Salinella; 37 Palude la Vela, 38 Foce Ofanto

1 Ramitelli-Saccione, 2 Lesina; 3 Varano; 4 Sfinale; 5 Farattarolo-Lago Salso; 6 Terra Apulie; 7 San Floriano; 8 Saline di Margherita; 9 Arisicanne; 10 Torre Canne; 11 Pantanagianni; 12 Torre Guaceto; 13 Foce Giancola; 14 Cillarese; 15 Punta della Contessa; 16 Lido Presepe; 17 Rauccio; 18 Acquatina; 19 San Cataldo; 20 Le Cesine, $21 \mathrm{Li}$ Tamari; 22 Laghi Alimini

Figure 3.

In order to analyse the importance and value of the salt works, we will use the Network Natura 2000 database for Apulia, created pursuant to Directive 79/409 Birds and Directive 92/43 Habitat.

Network Natura 2000 uses standardised procedures and criteria relative to the presence of habitats and rare and threatened species to identify a network of sites that are indispensable to the conservation of biodiversity in Europe. It is therefore a useful reference point for practical reports and the assessment of the environmental value of Apulia's wetlands.

We shall highlight their value and importance on the basis of the species and habitats of European interest to be found there. The Apulian wetlands are known to provide habitat for two species of fish, two species of reptiles, thirty-two species of nesting birds, not to mention the hundreds of bird species that winter there, and two species of mammals. It provides twenty-six habitats under EC Directive 92/43/EEC, six of which are priority habitats (Sigismondi, 2005).

Some of the charts drawn up by the Region of Apulia Parks Department, regarding the region's wetlands, are featured below.

N. al specie comunitarie per zona umıaa

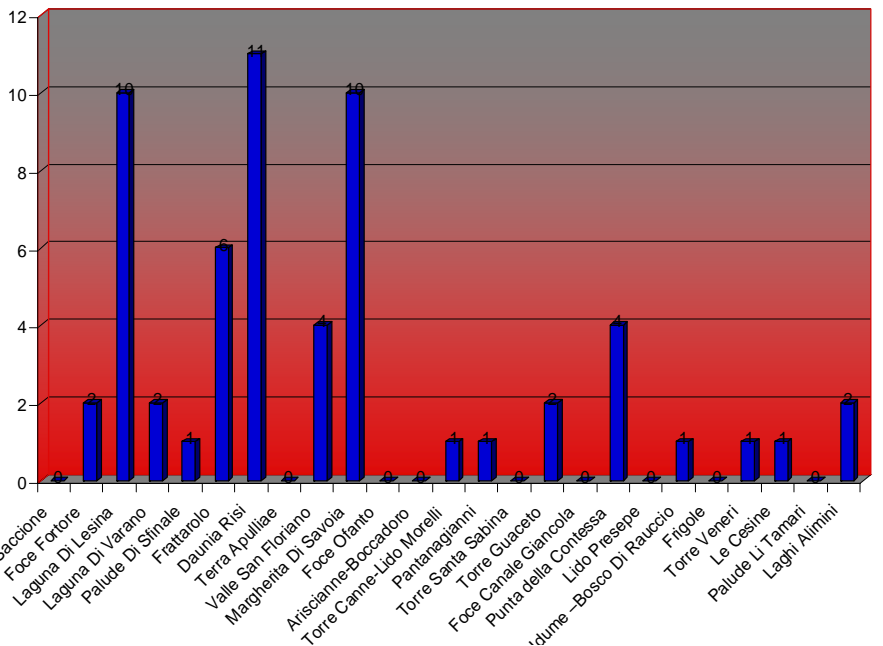

Figure 4. European species per wetland zone (Source: the Region of Apulia Parks Department) 


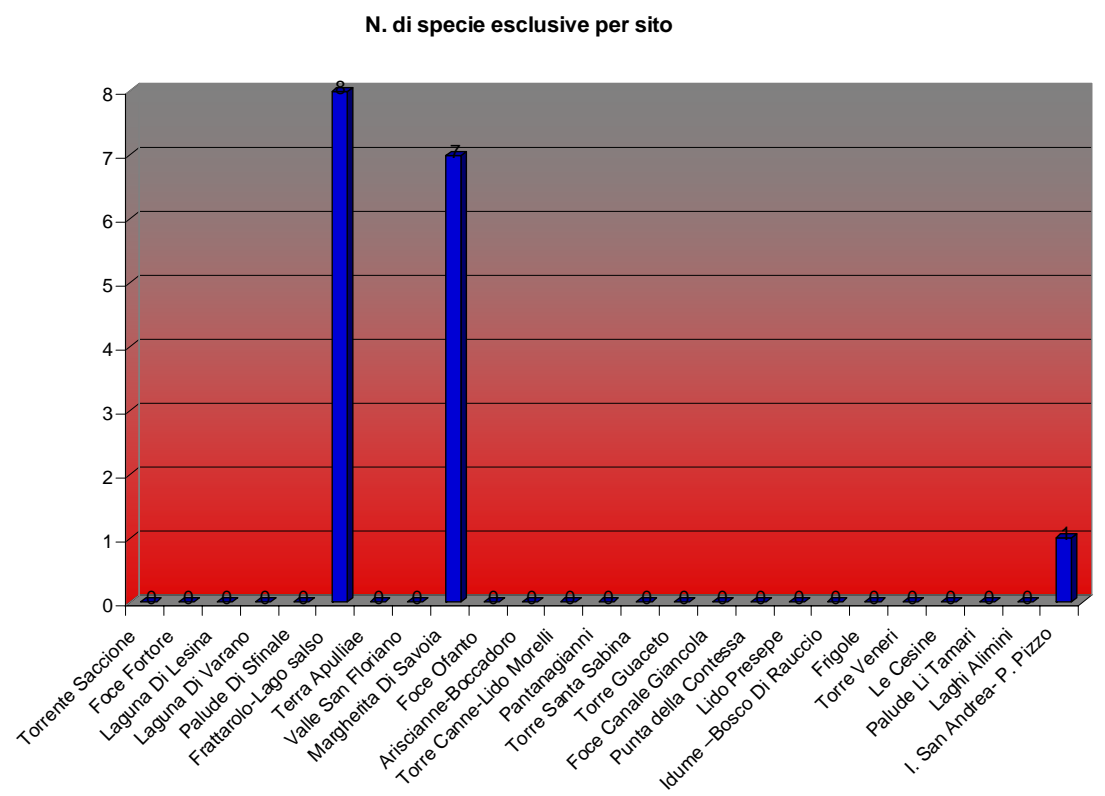

Figure 5. No. of exclusive species per site (Source: the Region of Apulia Parks Department)

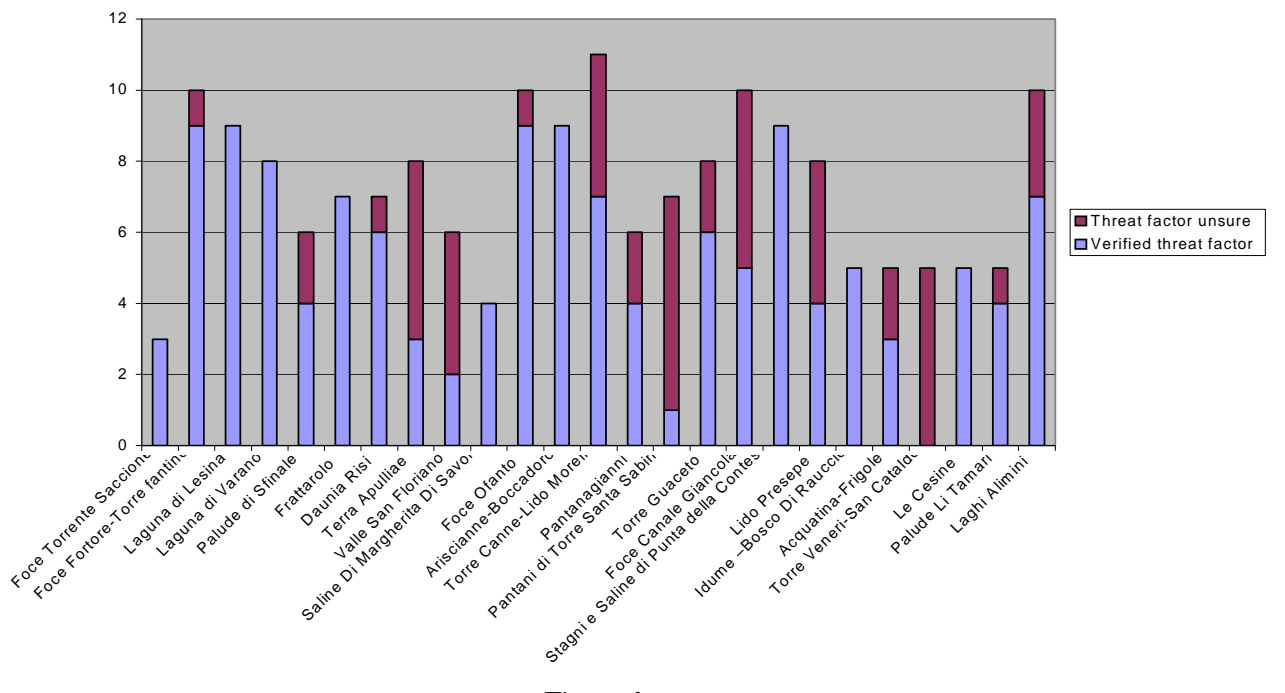

Threat factors

A1: Reclamations; A2: Modifications and transformations of the habitat (constructions buildings, roads, ports, concrete fluvial embnkments, climatic variations due to anthropic infuences, obstructions on the water course, water exploitation); A3: Alteration of the water capacities; A4: Ground filling; A5: Regression of the coast, alteration of the dunale system; A6: increase of the salinity; A7: Water Pollution; A8: Reduction and impoverishment of the primary producers; A9: Agriculture; A10: Activity of the free time (nautical tourism, bathing, sports, sport fishing, birdwatching, climbing); A11: Hunting; A12: Illegal hunting and fishing; A13: Fish farming, problems of management, excessive fishing; A14: Introduction species alloctone;

Figure 6. No. of threat and alteration factors per site Source: the Region of Apulia Parks Department

\section{THE "MARGHERITA DI SAVOIA SALTWORKS" WETLAND}

The information collected on nesting birds over the last thirty years demonstrates the presence of numerous species of international and European interest in this site, some of which have population levels of national importance. ${ }^{3}$ Consequently, this area is subject to a series of restrictions. On the basis of Italian law, the Office for the Administration of National Forests in the Gargano Area is responsible for protecting the area.

\footnotetext{
${ }^{3}$ The national importance is confirmed by the fact that the area is home to $1 \%$ of the national wintering population of 21 species of waterbirds.
} 
On $10^{\text {th }}$ October 1977 , the Ministry of Agriculture and Forestry included the salt works in the list of Italian State Protected Areas, classifying them as an Animal Nature Reserve.

On $30^{\text {th }}$ May 1979, the Margherita di Savoia salt works were declared a wetland of international importance, pursuant to the Ramsar Convention (Iran, 1971) ${ }^{4}$ in virtue of the criteria of $1 \%$ of the population of the following species: Tadorna tadorna (sheldrake), widgeon, Recurvirostra avocetta (avocet) (criteria 6) and with the criteria of 20,000 birds (criteria 5).

Moreover, the salt works were included in the Natura 2000 network, ${ }^{5}$ as site ZPS IT9110006 "Saline di Margherita di Savoia" of 4,860 hectares, falling almost entirely within pSIC IT9110005 "Zone umide di Capitanata" of 14,109 hectares"'.

The progressive increase in salinity and the varying depths of the salt pans, the presence of banks and channels, alternating with expanses of mud and the abundance of phytoplankton and zooplankton biomass, create a series of ecological niches that are ideal habitats for different species of aquatic birds. The birds occupy these areas on a seasonal basis, in keeping with their needs.

Therefore, by visiting the various areas of the salt works, it is possible to observe, within just a few kilometres from each other, aquatic species such as ducks and coots, typical of wetlands with relatively deep, non-salty water, and greater flamingos, which prefer the saltiest ponds, where the chemical and physical conditions of the waters would be prohibitive for other species.

The wealth of fauna in the area can also be explained in terms of the considerable dimensions of the wetlands, with their geographical position on migratory routes and their interaction with other Apulian wetlands. These salt works are therefore a fundamental stopping point during the migration of birds from breeding sites in Northern Europe to African wintering quarters. The number of wintering birds varies greatly from one year to the next, primarily depending on the weather conditions. It oscillates between 20 and 50,000 (a peak of 58,709 birds was recorded in 2000).

Hundreds of different bird species have been observed in the salt works. The most interesting migratory and wintering species, from a conservationist point of view, is the Numenius tenuirostris (slender-billed curlew), which is the bird most at risk of extinction in Europe. The Capitanata wetlands provide the most important stopping point for this bird on a national level and one of the most important in Western Europe. There also many other species of European interest, with some of the most regular visitors being the Phalacrocorax carbo (Pygmy Cormorant), the Egretta alba (Great white Egret), the Egretta garzetta (Little Egret), the Botaurus stellaris (Great Bittern), the Ciconia ciconia (White Stork), the Ciconia nigra (Black Stork), the Platalea leucorodia (Spoonbill), the Phoenicopterus ruber (Greater Flamingo), the Aythya nyroca (Ferruginous Duck), the Pluvialis apricaria (Golden Plover), the Philomachus Pugnax (Ruff), the Tringa glareola (Wood Sandpiper), the Limosa lapponica (Bar-tailed Godwit), the Phalaropus lobatus (Red-necked Phalarope), the Hydroprogne caspia (Caspian Tern, the Sterna sandvicensis (Sandwich Tern), the Chlidonias niger (Black Tern, the Falco biarmicus (Lanner Falcon), the Falco peregrinus (Peregrine Falcon), the Circus aëruginosus (Marsh harrier), the Circus cyaneus (Northern harrier), the Pandion haliaetus (Osprey) and the Asio flammeus (Short-eared Owl).

The sea beds are home to large populations of bivalves, which are a source of food for many bird species such as the sheldrake.

The reserve is also an important breeding ground for birds. It is home to the largest Italian colonies of Recurvirostra avocetta (Avocets), with over 650 pairs, of Larus melanocephalus (Mediterranean Gulls), with approximately 1000 pairs in some years, of Larus genei (Slenderbilled Gulls), with sometimes over 900 pairs being recorded, of Sterna albifrons (Little Terns),

\footnotetext{
4 “... This is one of the most important wetland zones in the Mediterranean and the most important in central and southern mainland Italy. It is a representative example of a water-dependent community characteristic of its biogeographical region. It represents one of the largest wetland areas in the Southern Adriatic that does not run the immediate risk of environmental transformation. It is located in a position that means that it can be readily used for scientific research and education. It is free from risks of major consequences as a result of external pollution, hydrobiological interference, alternative use of the territory and industrial activities ... ".

${ }^{5}$ The data in tables 1 - 2 indicates that at least 10 species from Network 2000 winter in the area, of which seven winter exclusively in this site
} 
with up to 600 pairs, and of Himantopus himantopus (Black-winged Stilts), with up to 140 pairs.

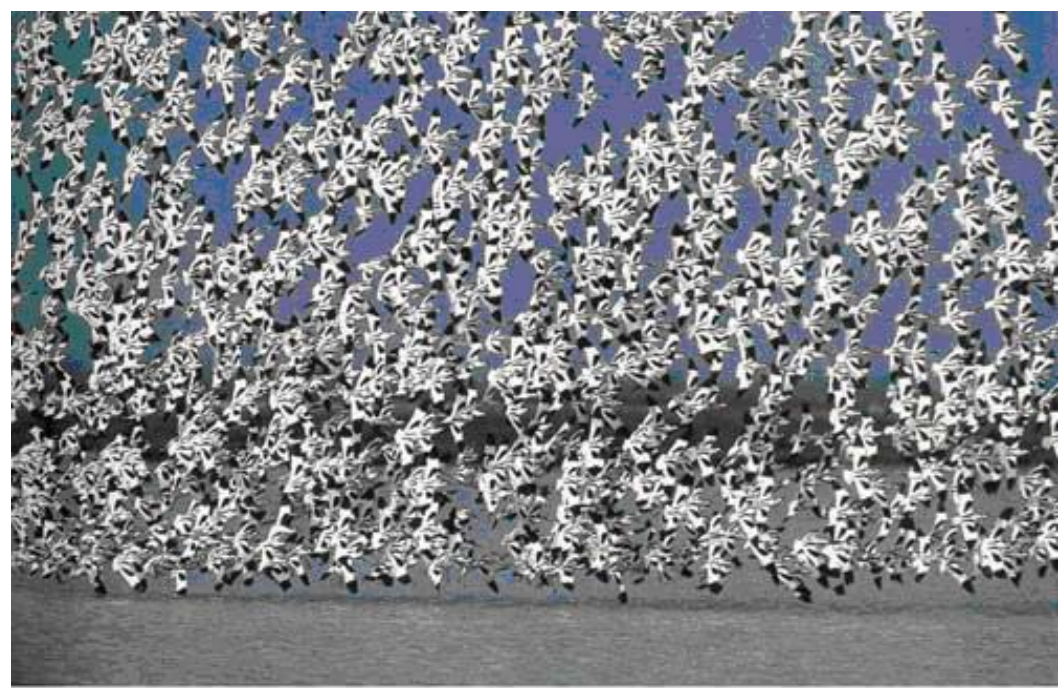

Figure 7. Avocets

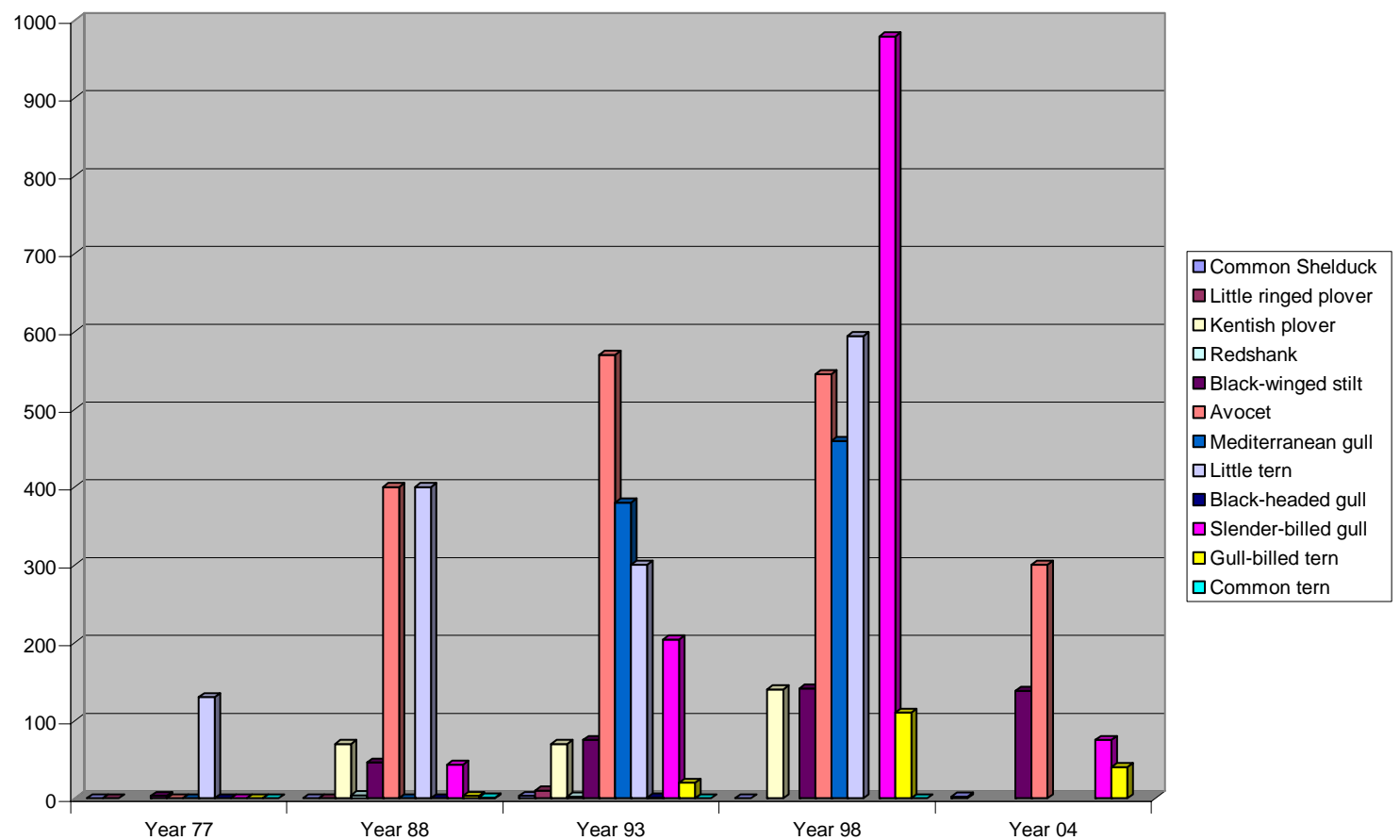

Figure 8. Nesting population trends Source: the Region of Apulia Parks Department

Some nests in the salt works are important not just in terms of numbers, but also in terms of the rarity of the species, such as those of the Gelochelidon nilotica (gull-billed tern), the Sterna sandvicensis (sandwich tern) and the Larus melanocephalus Mediterranean gull.

The Phoenicopterus ruber (greater flamingo) represents a special case, inasmuch as this species has colonised the reserve in great numbers over recent years. Flamingos began to settle in the shallower, saltiest ponds in the early 1990s, managing to breed within the salt works for the first time in 1996. The number of individuals has thus continued to climb, until reaching around 6,000 today, making it the largest concentration of the species in mainland Italy. These birds have therefore become a stable presence in the protected area, where their food abounds, primarily in the form of the crustacean

Artemia salina, the only invertebrate that can live in water with salinity of over $300 \%$, to 
they owe their pink colouring.

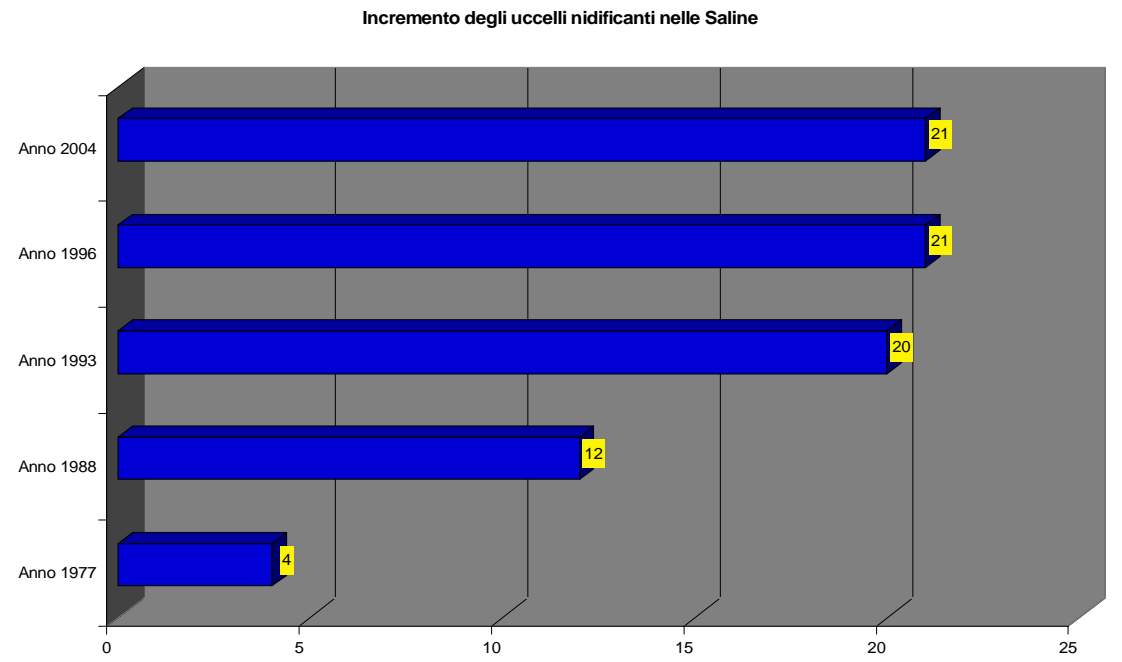

Figure 9. Increase in birds nesting in the Saltworks Source: the Region of Apulia Parks Department

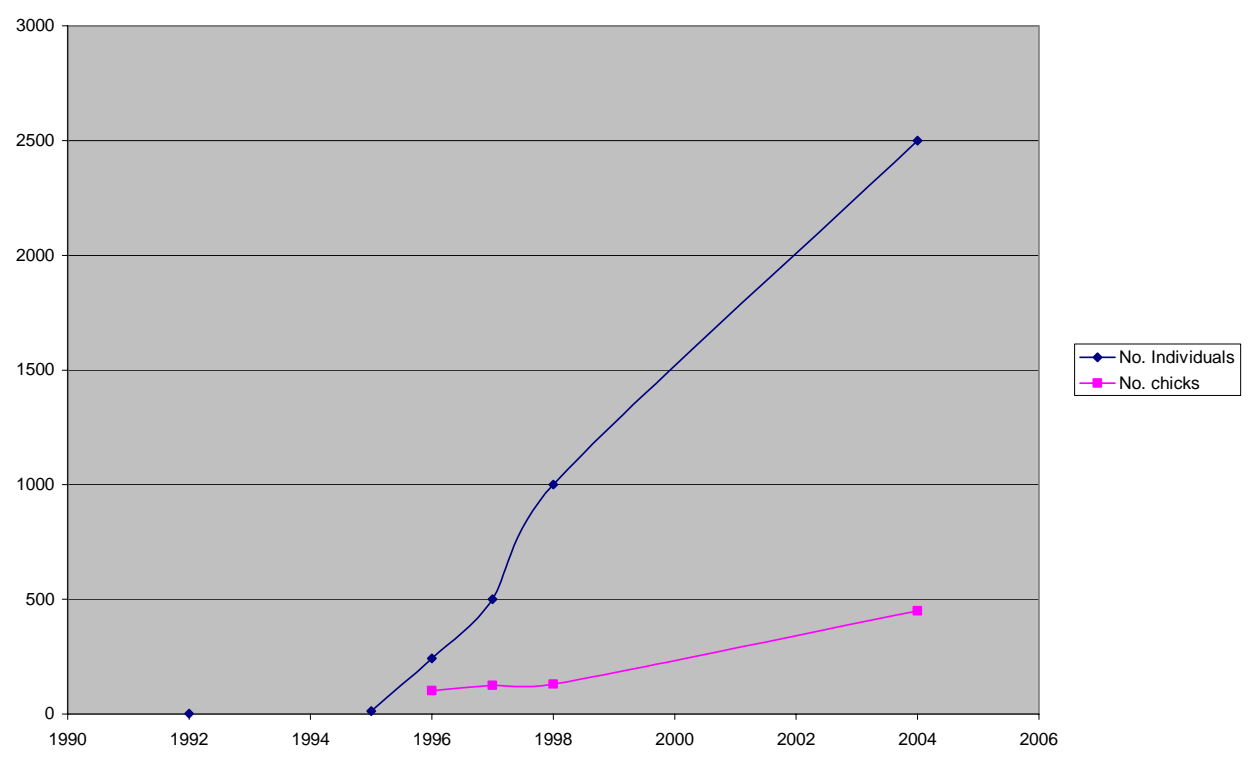

Figure 10. Flamingo population trends Source: the Region of Apulia Parks Department

\section{Ecological features, flora and Vegetation}

Research by the Italian Botanical Society indicates the presence of four habitats of European interest, including one of priority interest (coastal lagoons). This habitat is comprised of the deepest ponds, which are free from emerging vegetation and ecologically assimilable to actual lagoons with submerged, if rare and localised Ruppia maritima vegetation. It covers around $60 \%$ of the site and is classified as Chaetomorpho Ruppietum Br.-BI. 1952, Class Ruppietea J. Tx. 1960.

Althenia filiformis, a species on the National Red List, can be found in some wetlands in the proximity of the coast. The vast expanses of salt marsh characterise the Puccinellio festuciformis-Sarcocornietum fruticosae association (Br.-BI. 1928) J.M. Gèhu 1976 and the Puccinellio convolutae-Arthrocnemetum macrostachyi association (Br.-Bl. 1928) Gèhu 1984, Class Sarcocornietea fruticosae R. Tx. Et Oberd 1958.

We should also mention the following plant species found on the List of protected flora in Italy National Red List: Pilularia globulifera, Limonium avei, Limonium bellidifolium. 


\section{CONCLUSIONS}

Among the Apulian wetlands, the saltworks of Margherita di Savoia is certainly the one has the better conditions for the conservation of its ecosystem and guarantees the safeguard of the biodiversity. (tab. 3). It's importance in the national and international wetland context is well recognized. On the other these habitats have elements of fragility due to the difficult interaction with the surrounding territory and to the lack of boundary buffer areas. For this it's necessary to achieve a greater involvement of the interested municipalities, in order to develop a shared model of management of the territory, aware of the needs of environment, and in which it's clearly recognized the irreplaceable role of the sea salt production.

\section{REFERENCES}

Bissanti A., (1977), Le saline di Margherita di Savoia: localizzazione e cambiamenti nell'organizzazione del territorio. La terra del sale, (Margherita di Savoia saltworks: localization and changes in the territory organization. The land of salt

Davis J.S., (1999), Solar Saltworks: An Environmentally Friendly Industry, Proceedings of Post Conference Symposium Saltworks:Preserving Saline Coastal Ecosystems. Samos, Greece

Iommi G., (1941), Le Saline del Monopolio Italiano nell'Anno XVIII dell'Era Fascista, The saltworks of Italian Monopolies in the XVIII of the Fascist Age. Istituto poligrafico dello stato, Roma

Panella M., (1998), Information Sheet on Ramsar Wetlands: Saline di Margherita di Savoia, http://www.wetlands.org/reports/infosheet.cfm?siteref=3IT026

Serra L.,Magnani A., Dall'Antonia P., Baccetti N., (1997), Risultati dei censimenti degli uccelli acquatici svernanti in Italia (Census of wintering water-birds in Italy), Biol. Cons. Fauna 101

Sigismondi A., Apulia Parks Department, (2005), Le saline di Margherita di Savoia. Valore ed importanza nel sistema delle zone umide della Puglia. Atti del convegno, La produzione del sale e la salvaguardia dell'ecosistema. www. atisale.com (The Margherita di Savoia Saltworks: value and importance in the Apulian wetlands networks, Proceedings of the Conference, The production of sea salt and the safeguard of the ecosystem, http://www.atisale.com )

Zeno C., Sereno F., (2002) Margherita di Savoia: the Queen of the Mediterranean saltworks. Edizioni Cedel, Margherita di Savoia. 